\title{
worldview
}

A JOURNAL OF RELIGION AND INTERNATIONAL AFFAIRS

\section{NEITHER OMNIPOTENT NOR OMNISCIENT}

The citizenry of the United States is going through a vast and rapid education in international affairs. And as it does some cherished myths and illusions, held even by many who disclaim them, must fall by the way. Possibly some credit for the most recent and instructive public lectures in political affairs must go to those who provoked them-the political extremists.

There are in our society political extremists of the right who can understand contemporary politics, including United States foreign policy; only by postulating a vast conspiracy. Only a widespread conspiracy that reaches to the highest offices, they argue, can account for the reversals, the failures, the inertia and the ineptness that they attribute to the foreign and domestic policies of the United States during the last several decades. No person or agency is safe from their accusations: Congress, the Supreme Court and the Presidency have all been associated with the Communist conspiracy; the churches, Catholic and Protestant, have come under their judgment.

Unknown or ignored at first, these right-wing extremists have gained widespread local support and national attention. They have also earned local opposition and nation-wide criticism. Since they are able to find in most rebuttals further confirmation of their original assertions, these ultras of the right may be untouched by the mounting criticism that has been launched against them. Indeed, since several prominent and powerful leaders, political and religious, castigated them within the span of a few short weeks, they may uncover in this coincidence even new evidence of an interlocking conspiracy.

The Union of American Hebrew Congregations made one of the most common yet telling criticisms when it accused the ultra rightists of fomenting "division and hysteria" in the nation. The National Catholic Welfare Conference made a similar charge and warned against groups. which distract our attention from Communist activities abroad by stressing the dangers of sub- version at home. Dwight D. Eisenhower labelled as extremists those who would abolish the income tax and the unions and welcome a modified dictatorship. "I don't think the. U.S. needs superpatriots," he added.

The most important and most incisive comments, however, came from the man on whom finally rests the burden of our policies today, President John F. Kennedy. "We must face problems which do not lend themselves to easy, quick or permanent solutions," he said. "And we must face the fact that the United States is neither omnipotent nor omniscient, and that we cannot right every wrong or reverse each adversity, and that therefore there cannot be an American solution for every world problem."

- The President was pointing out truths that are only gradually becoming part of our national consciousness. Although the United States emerged from the second world war as the world's most powerful nation it did not become all-powerful. Nor did it suddenly attain an unlimited political wisdom. Some limits of our power are roughly outlined by our actions in Korea, in Laos, in Cuba and in Berlin. Other limits are evident in the difficulties we experience in reaching common agreement with our NATO allies. Still others are apparent in problems of coping with the changing European economic community and the shifting political patterns of Latin America. The disclaimer of national omnipotence and omniscience comes with particular relevance from one who shares the responsibility for our Cuban blunder. But the disclaimer applies as well to our dealings with allies and enemies around the world.

With these comments the President has engaged in that work of public education which is a proper and necessary part of Presidential leadership. The citizenry of a democracy can be expected to face the realities of its situation only if it is educated to recognize them. There is evidence, extremists aside, that American citizens are undergoing that painful process. 